\title{
The Use of Medicinal Aromatic Plants Against Bee Diseases and Pests
}

\author{
Erkan Topal ${ }^{1, *}\left(\mathbb{D}\right.$, Mihaiela Cornea-Cipcigan ${ }^{2}{ }^{(}$, Rahşan Ivgin Tunca ${ }^{3}(\mathbb{D}$, \\ Mustafa Kösoğlu' ${ }^{1}$, Rodica Margaoan ${ }^{4}[\mathbb{C}$
}

${ }^{1}$ Aegean Agricultural Research Institute, Apiculture Research Development Innovation Center, İzmir, Turkey

2 University of Agricultural Sciences and Veterinary Medicine, Faculty of Horticulture, Cluj-Napoca, Romania

${ }^{3}$ Muğla Sitki Kocman University, Ula Ali Kocman Vocational School, Muğla, Turkey

${ }^{4}$ University of Agricultural Sciences and Veterinary Medicine, Advanced Horticultural Research Institute of

Transylvania, Cluj-Napoca, Romania

\section{Article History}

Received 21 April 2020

Accepted 10 June 2020

First Online 31 July 2020

\section{*Corresponding Author \\ Tel.: +90232 8461331/ 1714 \\ E-mail: \\ topalerkan@tarimorman.gov.tr}

\author{
Keywords \\ Honeybees \\ Aromatic oil \\ Beekeeping \\ Good production practices
}

\begin{abstract}
Nowadays, aromatic plants and oils have significant contributions in growth performance, regulation of the digestive system and struggle with disease factors in farm animals. In beekeeping, many synthetic drugs are used against bee diseases and pests. Medicinal aromatic plants and oils, whose beneficial effects are known, are used in beekeeping in order to overcome the mentioned problems by natural means. In multiple researches it has been reported that herbs and essential oils of thyme, clove, mint, lemongrass, cinnamon, grapefruit, rosemary, marigold, laurel, eucalyptus and tea tree have lethal effects against mites, bacteria and fungi. When used appropriate doses, aromatic oils do not cause any toxic effects on the bee colony and have no negative effects on colony development. In addition, the use of medicinal aromatic herbs and oils in beekeeping supports organic production, as well as preventing residue problems in bee products (honey, beeswax and others).
\end{abstract}

\section{Introduction}

In order to combat/fight against diseases and improve the overall bee health, researchers are constantly developing medicines for honey bees by the use of microbiology, molecular biology and chemistry tools (Tauber et al., 2019). The effects of medicinal herbs have been known since ancient times, and in traditional healing, these herbs have been used to treat diseases from past to present. With the development of the scientific perspective, the compounds and active substances contained in these plants were identified. Thus, mechanisms of action against microorganisms causing diseases in humans, animals and plants have been discovered. The reason for this is the search for natural or environmental-friendly compounds that can be effectively and safely used as an alternative to pesticides (Altundağ \& Aslım, 2005).
Generally, aromatic plant essential oils are obtained by steam and/or water distillation from the plants themselves or related parts. They contain volatile compounds (alcohols, esters, aldehydes, ketones etc.), non-volatile compounds (paraffin, wax etc.) and hydrocarbons (terpenes, sesquiterpenes etc.) (Losa, 2001). Nowadays, both aromatic plants and essential oils are used in poultry, rabbit and ruminant diets. A wide variety of essential oils have multiple positive effects on animals in regards to growth performance, digestive system, etc. They have also been reported to contain bioactive compounds that have the potential to act as multi-functional feed supplements (Bento et al., 2013; Cho et al., 2006; Hundal, Wadhwa \& Bakshi, 2016; Küçükyılmaz et al., 2017; Simitzis, 2017; Ünal \& Kocabağlı, 2014; Zeng, Zhang, Wang, \& Piao, 2015).

The antimicrobial activity of essential oils in both human, animal nutrition and overall health depends on 
the chemical content of the active ingredients. There are differences in the content even within the same plant species. It is known that medicinal and aromatic plants may have adverse effects when taken in higher doses. For this reason, the effectiveness of the plant or oil used in this treatment system must be evaluated and demonstrated with more detailed scientific research (Kammon, 2017; Niculae et al., 2009; Novak, ZitterlEglseer, Deans, \& Franz, 2001).

In later periods, plant-based insecticides have been used in bee colonies to fight parasites and pathogens (Blenau, Rademacher, \& Baumann, 2011). Recent studies have demonstrated that thyme oil, blueberry oil, eucalyptus oil, walnut leaf oil, bay leaf oil, blackgrass oil, pine oil, guar gum, andiroba oil, citronella oil, garlic extract and other vegetable oils were used on bees. This and similar plants have been demonstrated to positively affect both colony development, along with health and bees behaviour (Bekret, Çankaya, \& Silici, 2015; Higginson, Gilbert, \& Reader, 2007).

In traditional beekeeping, many drugs and insecticides such as acaricides, fumigants, antibiotics are used for both bee pests and diseases such as Varroa destructor (Varroa mite), Acarapis woodi (tracheal mite), Galleria mellonella (large wax moth), American foulbrood, European foulbrood, Nosema etc. (Mert, Yücel, \& Kösoğlu, 2007). Unconscious use of drugs leads to the resistance of disease factors, damage to beneficial microorganisms for bees and colonies, as well as residue problems in products obtained from beekeeping. For these reasons, alternative treatments or control methods are needed.

Recent studies have shown that essential oils of plants such as thyme, clove, peppermint, lemon grass, cinnamon, grapefruit, rosemary, marigold, eucalyptus, tea tree have positive effects against some mites, bacteria and fungi. In addition, active ingredients such as sanguinarin, thymoquinone, capsaicin, carvacrol, citral, eugenol, thymol isolated from these plants have been reported to have these effects on organisms (Demirel, Keskin, \& Kumral, 2019; Khan et al., 2019; Tutun, Koç, \& Kart, 2018). Recently, organic acids and essential oils are among the natural treatment methods for fighting against diseases in beekeeping. The most important point to note is that although the methods used are considered as natural ingredients, the usage doses should not be exceeded (Glavan, Novak, Božič, \& Kokalj, 2020; Pinheiro et al., 2019; Porrini et al., 2017). In general, beekeepers use essential oils as an alternative to synthetic drugs for rotational purposes and also to prevent residues in bee products. To summarize, essential oils and essential oil compounds are used as an alternative treatment model against synthetic drugs.

In this review, the studies about some aromatic plants used in beekeeping and the effects of plants on bee health have been discussed.

\section{Aromatic Plants Used in Beekeeping}

Since the middle ages, citrus essential oils (lemon, citrus etc.) have been widely used in medicinal products such as bactericidal, virucidal, fungicidal, antiparasitic, insecticidal. Additionally, today, their active ingredients are used in the pharmaceutical, healthcare, cosmetic, agricultural, food and beekeeping industries. The best method of removing essential oils from citrus vegetable tissue is steam distillation, resulting in various volatile molecules extracted, such as terpenes and terpenoids, aromatic components derived from phenol and aliphatic components (Albo et al., 2003; Palazzolo, Laudicina, \& Germana, 2013). Some compounds of lemon oil, the pheromone nasonov contains geranium, citral and geraniol. Lemon oil is used in different ways with honey bees, such as supplemental foods to increase the quality of the bees' food, encourage them to eat, soothe the bees and introduce the new queen. In addition, it has been claimed that the use of lemon balm (Melissa officinalis L.) in the hive is effective in attracting honeybee swarms (Allam \& Zakaria, 2009; Burgett, 1980; Manning, Speijers, Harvey, \& Black, 2010). Thyme (Thymus vulgaris L.) is a perennial herbaceous plant with a wide distribution area, having aromatic flowers (pink or white) and woody stems. Thyme oil, obtained by distillation from the flowering branches, is rich in thymol and carvacrol. Thymol is one of the most used essential oils in the treatment of varroa mites (Varroa destructor). Again, all the essential oils in the Lamiaceae (peppermint) family can be used to help control varroa. The mint plant, which has antifungal characteristics, is also used for the treatment of Chalkbrood or for the prevention of other diseases (Albo et al., 2003; Kouache et al., 2017; Tutkun, 2016). Rusenova and Parvanov (2009) demonstrated that the most powerful essential oils were reported in cinnamon, lemon grass and thyme plants according to the dilution method of agar. In general, mint is used as pheromone masking aroma due of its active compounds for bee pheromones. Curly peppermint (Mentha $x$ piperita L.) is usually used with lemon oil during feeding to improve the health of the hive, is also used in the fight against varroa mites. Thymol and eucalyptus oils are known to be used to control varroa mites (Ariana, Ebadi, \& Tahmasebi, 2002; Ismail, Ghoniemy, \& Owayss, 2006). Bakar et al. (2017) evaluated the efficacy of eucalyptus, neem, lemon and orange oil at different doses against percent mortality of Varroa mites. Their results showed that the highest mortality percentage was observed in eucalyptus oil (76.13\%) at $2.5 \mathrm{~mL}$ dose. It has also been reported that menthol is used for the control of tracheal mites. It has been established that all essential oils, with the exception of orange oil, are used to combat varroa mites. For example, in a recent study of Bakar et al. (2019) in vitro studies were conducted in order to assess the efficacy of multiple essential oils against percent mortality of $V$. destructor mites. Their experiments showed that after 72 hours at 400 ppm concentration, 
neem and eucalyptus oil showed the most promising results with a mortality percentage of $90 \%$ and $83.3 \%$, respectively (Bakar et al., 2019). It is reported that the grey partridge (Perdix perdix) can be used to control the trachea mite and is useful against the small beetle when using the tea tree varroa (Amrine, Noel, Mallow, Stasny, \& Skidmore, 1996a; Gashout \& Guzmán-Nova, 2009; Imdorf, Bogdanov, Ochoa, \& Calderone, 1999).

\section{Studies on Bee Health of Medicinal Aromatic Plants and Oils}

The studies of aromatic plants and oils which were used against diseases and pests of bees in recent years are summarized in Table 1.

The production potential of honey bee colonies depends on the colonies' health status. The use of aromatic plant extracts in late winter together with protein feed offered to bee colonies can be regarded as a method that has a positive effect on both improving bee health and colony's honey production. It has been reported that feeding bees with enriched garlic, echinacea, red reishi mushrooms and protein enriched sugar containing sage extracts increases the incubation of queen bee, compared to the vegetable extract used in the number of bacterial groups in the worker bees ((Pătruıcă, Moț, \& Popovicı, 2017).

The herbal products used in Varroa control are generally inexpensive and most of them pose little health risk. Terpenes (mainly monoterpenes) are the main compounds that make up $90 \%$ of the essential oils. In laboratory screening tests, over 150 essential oils and their compounds were evaluated. However, while very few were successful in field experiments, thymol and thymol mixtures proved to be a promising exception (Imdorf et al., 1999). The extract and leaves of many plants, such as tobacco, pine leaf, garlic, thyme, eucalyptus, juniper, peppermint, pear, walnut, citrus, teal and cumin are used in the fight against Varroa. These types of applications are $40-75 \%$ effective in reducing the varroa population, but these plants, which are kept in a very dense colony, can have negative effects on queen bees, due to their strong odour (Witherel \& Bruce, 1990). Cinnamon oil, eucalyptus oil, pepper oil, green tea oil, neem oil and thyme oil are used in varroa control in multiple countries (Amrine, Noel, Mallow, Stasny, \& Skidmore, 1996b). In another study, the success of $0.75 \mathrm{mg}$ of menthol, cloves, origanum and thymol oil used to control mites was reported at $87 \%$, $96 \%$, and $100 \%$, respectively (Gashout \& Guzmán-Novoa 2009).

Table 1. Medicinal plants used against several bee diseases and pests.

\begin{tabular}{|c|c|c|}
\hline $\begin{array}{l}\text { Disease and/or } \\
\text { harmful factor }\end{array}$ & Plant or oil used & References \\
\hline Varroa destructor & $\begin{array}{l}\text { Thymus kotschyanus Boiss. \& Hohen. } \\
\text { Azadirachta indica A.Juss. (neem or Indian } \\
\text { lilac) } \\
\text { Foeniculum vulgare Mill (fennel) oil } \\
\text { Syzygium aromaticum (L.) Merr. \& L.M.Perry } \\
\text { (clove) oil }\end{array}$ & $\begin{array}{l}\text { Emsen and Dodoloğlu, 2015; } \\
\text { Ghasemi, Moharramipour, \& } \\
\text { Tahmasbi, 2011; } \\
\text { González-Gómez et al., 2012; } \\
\text { Gunes et al., 2017; } \\
\text { Sabahi, Gashout, Kelly, \& Guzman- } \\
\text { Novoa, 2017; } \\
\text { Li et al., 2017; Lin et al., } 2020\end{array}$ \\
\hline Tropilaelaps spp & Illicium verum Hook. f. (True star Anise tree) & Su, Hua, Zhao, Fei \& Zheng, 2016 \\
\hline Paenibacillus larvae & $\begin{array}{l}\text { Cinnamomum verum J.Presl (cinnamon) oil; } \\
\text { Citrus limon (L.) Burm. f. (lemon) oil }\end{array}$ & $\begin{array}{l}\text { Alippi et al., 1996; } \\
\text { Fuselli, de la Rosa, Eguaras, \& Fritz, } \\
2008\end{array}$ \\
\hline $\begin{array}{l}\text { Chalkbrood disease } \\
\text { (Ascosphaera apis) }\end{array}$ & $\begin{array}{l}\text { Andrographis paniculata (Burm.f.) Nees } \\
\text { (creat or green chireta) }\end{array}$ & $\begin{array}{l}\text { Calderone et al., 1994; } \\
\text { Davis and Ward, } 2003\end{array}$ \\
\hline Nosema apis & $\begin{array}{l}\text { Thymol extracted from Thymus vulgaris } \\
\text { (thyme) }\end{array}$ & $\begin{array}{l}\text { Chen et al., 2019; } \\
\text { Costa, Lodesani, \& Maistrello, } 2010\end{array}$ \\
\hline $\begin{array}{l}\text { Black queen cell virus } \\
\text { (BQCV) }\end{array}$ & Laurus nobilis L. extract & Aurori et al., 2016 \\
\hline
\end{tabular}


The most effective result in Thymus kotschyanus Boiss. \& Hohen (thyme), Ferula assa-foetida L. (asafetida) and Eucalyptus camaldulensis Dehnh. (river red gum) essential oils, which evaluated the acaricidal activity against Varroa destructor, was obtained with $T$. kotschyanus (Ghasemi, Moharramipour \& Tahmasbi, 2011). Ethanolic extracts of Baccharis flabellate Hook \& Arn (baccharises) and Minthostachys verticillata (Griseb.) Epling (peperina) have been shown to be highly effective against mites, and their applications did not have a negative effect on bees (Damiani et al., 2011). As essential oils positively affect the caring behaviour of honey bee colonies against varroa (Abd El Wahab, Ebadah, \& Zidan, 2012), it has been reported that the concentration of $21.1 \%$ of neem seed oil (Azadirachta indica) led to $100 \%$ mortality percentage of Varroa mites after 72 hours (González-Gómez, Otero-Colina, Villanueva-Jiménez, Peña-Valdivia, \& Santizo-Rincón, 2012).

In the study conducted with Lepidium latifolium L. (perennial pepperweed), from Brassicaceae family and the Zataria multiflora Boiss. (Shirazi thyme) leaf extract against $V$. destructor, the methanolic extracts $(100,200$, 400 and 500 ppm) were applied to hives in 4 different concentrations. Acaricide activity was determined to be the highest (100\%) for L. latifolium extract at 500 ppm after 12 days and $86.26 \%$ for Z. multiflora. It has been reported that both extracts can be used for varroa on bees and that there are no acknowledged negative effects on honey bee colonies (Razavi, Asadpour, Jafari, \& Malekpour, 2015). In another study performed in the same year, it was reported that $10 \mathrm{~g}$ of thyme added to bee cake had a mortality percentage of $92.85 \%$ in Varroa mite (Emsen \& Dodoloğlu, 2015). Seven different treatment groups were created to combat varroa using mixtures of formic, oxalic acid and thymol-menthol in order to examine their impact on Heat Shock Proteins (HSP 70) in the brain tissues of bees. It was observed that HSP 70 was lower in the groups exposed to varroa treatment than in the untreated groups, and the thymol-menthol mixture was lowest in the exposed group among the treated groups (Güneș et al., 2017). In recent years, excessive use of traditional acaricides, such as tau fluvalinate and flumethrin against Varroa, has played an important role in colony losses; which has only increased its tolerance to them. Therefore, the application of essential oils on traditional pesticides has been reported as an alternative fighting option, with high yield, minimum residues and tolerance or resistance to mites (Li et al., 2017). In China, Dalbergia odorifera T. Chen (Odoriferous Rosewood) oil and Foeniculum vulgare (fennel) oil have been reported to be effective against over $65 \%$ of Varroa and have a high potential for varroacidal administration as a fumigant agent (Lin et al., 2020). To study the acaricidal activity of essential oils, clove oil (Syzygium aromaticum L.), a typical essential oil, with a wide range of field applications, was used to study its effects on enzyme activities of $\mathrm{Ca}^{2+}-\mathrm{Mg}^{2+}$-ATPase, glutathione-S- transferase (GST) and superoxide dismutase (SOD). Furthermore, its effects on the water-soluble protein content of Varroa body extracts after exposure to $0.1 \mu \mathrm{L}$ and $1.0 \mu \mathrm{L}$ of clove oil for $30 \mathrm{~min}$ was evaluated. The results showed that the water soluble protein content decreased significantly after the treatments, negatively affecting the mites' metabolism (Li et al., 2017).

Some essential oils were reported to be partially effective in determining the success of natural products in controlling the in vitro development of Ascosphaera apis. Oils that contain lemon extract as the main ingredient in its structure suppress fungi development at a concentration of $250 \mathrm{ppm}$. They found that Corymbia citriodora (Hook.) K.D.Hill \& L.A.S.Johnson (lemon-scented gum), Leptospermum petersonii F.M.Bailey (lemon-scented teatree), Leptospermum scoparium J.R.Forst \& G.Forst (mānuka) are more effective (Davis \& Ward, 2003).

Paenibacillus larvae are one of the major bacterial pathogens that infect bee larvae and are a cause of American disease. Due to the increased resistance to commonly used antibiotics and the residual problem in the honey bee product, it is necessary to discover new agents to control this disease (Ansari et al., 2016). In the study conducted using eight plant extracts to determine their efficacy in P. larvae, Ascosphaera apis and Paenibacillus alvei larvae, 100 ppm cinnamon oil completely suppressed $A$. apis development for 7 days, whereas laurel, lemon, clove and thyme oil prevented their development at 1000 ppm for 7 days (Calderone, Shimanuki, \& Allen-Wardell, 1994). In a different study, essential oils derived from aromatic plants such as thyme (Satureja hortensis, Origanum vulgare, Thymus vulgaris), lavender (Lavandula hybrids), eucalyptus, lemon grass (Cymbopogon citratus (DC.) Stapf), peppermint (Mentha $x$ piperita), Salvia rosmarinus (rosemary). The antimicrobial activity against larvae was analyzed by in vitro study. It was found that among the tested essential oils lemon and thyme were the most effiecient in suppressing the development of Paenibacillus larvae. On the contrary, oils obtained from rosemary and eucalyptus plants showed a low antibacterial effect against Paenibacillus larvae. It was observed that instead of pure essences or their essential ingredients, mixtures of essential oils may show greater efficacy against $P$. larvae (Alippi, Ringuelet, Cerimete, $\mathrm{Re}, \&$ Henning, 1996). The in vitro antibacterial activities of 28 essential oils of plants against P. larva ATCC 9545 were evaluated. Jamaican pepper oil, mountain pepper oil, ajwain oil (thymol), peppermint oil, star anise oil, oconut oil and camphor oil have been reported to be quite effective. Essential oils tested have shown significant antimicrobial activity against $P$. larvae. It was also reported that they may contain compounds that play an important role in the treatment or prevention of American foulbrood (Ansari et al., 2016).

The effect of 8 types of herbal extracts against $N$. ceranae infection was investigated under laboratory conditions to find alternative medicines to fight the 
nosema disease. It has been found that $1 \%$ of the source of Andrographis paniculata significantly reduces the number of $N$. ceranae spores at 7 days after infection (Chen et al., 2019).

Aurori, Bobis, Dezmirean, Mărghitas, and Erler (2016) evaluated the antiviral potential of Laurus nobilis leaf ethanolic extracts on forager honeybees naturally infected with BQCV. Their results showed that higher extract concentrations ( $\geq 5 \mathrm{mg} / \mathrm{mL}$ ) significantly reduced virus replication, observing that viral loads decreased even at the lowest tested concentration $(1 \mathrm{mg} / \mathrm{mL})$. Researchers have revealed that secondary plant metabolites can reduce virus loads and virus replication in infected honey bees.

\section{Conclusion}

It is important to fight against/combat diseases and pests by using biological and organic methods because of suitable production models for healthy foods. As a result of the banned of some chemicals for animals breeding, medicinal and aromatic plants and oils have been commonly used. While some of the medicinal and aromatic plants are collected from nature, some of them are grown and produced commercially. It should be noted that carrying out studies with cultivated plants can facilitate the standardization of their chemical compunds. The compounds used against diseases and pests, as well as the dosage will reveal its positive effect on bee colony, as well as the environment. In many studies, it has been reported that alternative methods used in the organic control of both pest and diseases do not have toxic effects on larvae, pupae and adults and do not adversely affect colony development when they used at appropriate doses.

\section{References}

Abd El Wahab, T., Ebadah, I., \& Zidan, E. (2012). Control of Varroa Mite by Essential Oils and Formic Acid with Their Effects on Grooming Behaviour of Honey Bee Colonies. Journal of Basic and Applied Scientific Research, 2(8), 7674-7680.

Albo, G.N., Henning, C., Ringuelet, J., Reynaldi, F.J., De Giusti, M.R., \& Alippi, A.M. (2003). Evaluation of some essential oils for the control and prevention of American Foulbrood disease in honey bees. Apidologie, 34(5), 417427.

Alippi, A.M., Ringuelet, J. A., Cerimete, E.L., Re, M.S., \& Henning, C.P. (1996). Antimicrobial activity of some essential oils against paenibacillus larvae, the casual agent of american foulbrood disease. Journal of Herbs, Spices \& Medicinal Plants, 4(2), 9-16.

Allam, S., \& Zakaria, M. (2009). Stimulation effects of the essential oils on the sensory and defensive behaviors of Egyptian honey bees towards Varroa invasion. Acarines: Journal of the Egyptian Society of Acarology, 3(1), 29-36.

Altundağ, Ş., \& Aslım, B. (2005). Kekiğin bazı bitki patojeni bakteriler üzerine antimikrobiyal etkisi. Orlab On-Line Mikrobiyoloji Dergisi, 3(7), 12-14.
Amrine, J., Noel, B., Mallow, H., Stasny, T., \& Skidmore, R. (1996a). Essential oils used to control mites in honey bees. Retrieved from www.wvu.edu/agexten/varroa/ oils.htm

Amrine, J., Noel, B., Mallow, H., Stasny, T., \& Skidmore, R. (1996b). Results of research: using essential oils for honey bee mite control. Retrieved from: http://www.natuerliche-bienenhaltung.ch/pdf/ Essential_Oils_for_mite_control.pdf

Ansari, M.J., Al-Ghamdi, A., Usmani, S., Al-Waili, N., Nuru, A., Sharma, D., ... Omer, M. (2016). In vitro evaluation of the effects of some plant essential oils on Paenibacillus larvae, the causative agent of American foulbrood. Biotechnology \& Biotechnological Equipment, 30(1), 4955.

Ariana, A., Ebadi, R., \& Tahmasebi, G. (2002). Laboratory evaluation of some plant essences to control Varroa destructor (Acari: Varroidae). Experimental \& Applied Acarology, 27(4), 319-327.

Aurori, A.C., Bobis, O., Dezmirean, D.S., Mărghitas, L.A., \& Erler, S. (2016) Bay laurel (Laurus nobilis) as potential antiviral treatment in naturally BQCV infected honeybees. Virus Research, 222, 29-33.

Bakar, M. A., Aqueel, M. A., Raza, A. B. M., Ullah, M. I., Arshad, M., Sohail, M., \& Molina-Ochoa, J. (2017). Evaluation of Few Essential Oils for the Management of Parasitic Bee Mites, Varroa destructor (Acari: Varroidae) in Apis mellifera L. Colonies. Pakistan Journal of Zoology, 49(6), 2005-2010.

Bakar, M.A., Aqueel, M.A., Raza, A.B.M., Mahmood, R., Qadir, Z. A., Arshad, M., \& Sohail, M. (2019). Evaluation of essential oils for the management of parasitic bee mites, Varroa destructor (Acari: Varroidae) in vitro. Pakistan Journal of Agricultural Research, 32(4), 566-571.

Bekret A., Çankaya S., \& Silici S. (2015). Bal arısı şurubuna katılan bitki ekstraktı ve yağlarından oluşan karışımının koloni gelişimi ve bal verimi üzerine etkileri. Türk Tarım - Gıda Bilim ve Teknoloji Dergisi, 3(6), 365-370.

Bento, M.H.L., Ouwehand, A.C., Tiihonen, K., Lahtinen, S., Nurminen, P., Saarinen, M.T., ... \& Fischer, J. (2013). Essential oils and their use in animal feeds for monogastric animals--Effects on feed quality, gut microbiota, growth performance and food safety: a review. Veterinarni Medicina, 58(9), 449-458.

Blenau, W., Rademacher, E., \& Baumann, A. (2011) Plant essential oils and formamidines as insecticides/ acaricides: what are the molecular targets? Apidologie, 43, 334-347.

Burgett, M. (1980). The use of lemon balm (Melissa officinalis) for attracting honeybee swarms. Bee World, 61, 44-46.

Calderone, N.W., Shimanuki, H., \& Allen-Wardell, G. (1994). An in vitro evaluation of botanical compounds for the control of the honey bee pathogens Bacillus larvae, and Ascosphaera apis, and the secondary invader B. alvei. Journal of Essential Oil Research, 6,279-287.

Chen, X., Wang, S., Xu, Y., Gong, H., Wu, Y., Chen, Y., ... Zheng, H. (2019). Protective potential of Chinese herbal extracts against microsporidian Nosema ceranae, an emergent pathogen of western honey bees, Apis mellifera L. Journal of Asia-Pacific Entomology. https://doi.org/10.1016/j.aspen.2019.08.006

Cho, J.H., Chen, Y.J., Min, B. J., Kim, H.J., Kwon, O.S., Shon, K. S., \& Asamer, A. (2006). Effects of essential oils supplementation on growth performance, IgG concentration and fecal noxious gas concentration of 
weaned pigs. Asian Australasian Journal of Animal Sciences, 19(1), 80-85.

Costa, C., Lodesani, M., \& Maistrello, L. (2010). Effect of thymol and resveratrol administered with candy or syrup on the development of Nosema ceranae and on the longevity of honeybees (Apis mellifera L.) in laboratory conditions. Apidologie, 41(2), 141-150.

Damiani, N., Gende, L.B., Maggi, M.D., Palacios, S., Marcangeli, J.A., \& Eguaras, M.J. (2011). Repellent and acaricidal effects of botanical extracts on Varroa destructor. Parasitology research, 108(1), 79-86.

Davis, C., \& Ward, W. (2003). Control of chalkbrood disease with natural products (Pub. No: 03/07). Rural industries Research and Development Corporation., 23 pp.

Demirel, M., Keskin, G., \& Kumral, N.A. (2019). Varroa mücadelesinde sentetik ve organik akarisitlerin kullanım olanakları. Uludag Bee Journal, 19(1), 96-109.

Emsen, B. \& Dodoloğlu, A. (2015). The efficacy of thymol and oxalic acid in bee cake against bee mite (Varroa destructor Anderson\&Trueman) in honey bee (Apis mellifera L.) colonies. Kafkas Üniversitesi Veteriner Fakültesi Dergisi, 21, 41-45.

Fuselli, S. R., de la Rosa, S. B. G., Eguaras, M. J., \& Fritz, R. (2008). Chemical composition and antimicrobial activity of Citrus essences on honeybee bacterial pathogen Paenibacillus larvae, the causal agent of American foulbrood. World Journal of Microbiology and Biotechnology, 24(10), 2067-2072.

Gashout, H. A. \& Guzmán-Novoa, E. (2009). Acute toxicity of essential oils and other natural compounds to the parasitic mite, Varroa destructor, and to larval and adult worker honey bees (Apis mellifera L.). Journal of apicultural research, 48(4), 263-269.

Ghasemi, V., Moharramipour, S., \& Tahmasbi, G. (2011). Biological activity of some plant essential oils against Varroa destructor (Acari: Varroidae), an ectoparasitic mite of Apis mellifera (Hymenoptera: Apidae). Experimental and applied acarology, 55(2), 147-154.

Glavan, G., Novak, S., Božič, J., \& Kokalj, A.J. (2020). Comparison of sublethal effects of natural acaricides carvacrol and thymol on honeybees. Pesticide Biochemistry and Physiology, 166, 104567.

González-Gómez, R., Otero-Colina, G., Villanueva-Jiménez, J. A., Peña-Valdivia, C.B., \& Santizo-Rincón, J.A. (2012). Repellency of the oily extract of neem seeds (Azadirachta indica) against Varroa destructor (Acari: Varroidae). Experimental and Applied Acarology, 56(3), 261-270.

Güneş, N., Aydın, L., Belenli, D., Hranitz, J. M., Mengilig, S., \& Selova, S. (2017). Stress responses of honey bees to organic acid and essential oil treatments against varroa mites. Journal of Apicultural Research, 56(2), 175-181.

Higginson, A.D., Gilbert, F.S., \& Reader, T. (2007). Reduction of visitation rates by honeybees (Apis mellifera) to individual inflorescences of lavender (Lavandula stoechas) upon removal of coloured accessory bracts (Hymenoptera: Apidae). Entomologia Generalis, 29, 165-178.

Hundal, J.S., Wadhwa, M., \& Bakshi, M.P.S. (2016). Effect of supplementing essential oils on the in vitro methane production and digestibility of wheat straw. Journal of Animal Research and Nutrition, 1(3).

Imdorf, A., Bogdanov, S., Ochoa, R.I., \& Calderone, N.W. (1999). Use of essential oils for the control of Varroa jacobsoni Oud. in honey bee colonies. Apidologie, 30 (2-
3), 209-228.

Ismail, A. M., Ghoniemy, H. A., \& Owayss, A. A. (2006, January). Combatting honeybee Varroa mites by plant oils alone or in an IPM program. In: The $2^{\text {nd }}$ Conference of Farm Integrated Pest Management, (pp.172-185).

Kammon, A. M. (2017). The Future Use of Medicinal Plants as Alternatives to Antibiotics in Animal Health and Production. Microbiol Rev., 12(4), 564-582.

Khan, S.U., Anjum, S.I., Ansari, M. J., Khan, M. H. U., Kamal, S., Rahman, K., ... Khan, D. (2019). Antimicrobial potentials of medicinal plant's extract and their derived silver nanoparticles: A focus on honey bee pathogen. Saudi Journal of Biological Sciences, 26(7), 1815-1834.

Kouache, B., Brada, M., Saadi, A., Fauconnier, M. L., Lognay, G., \& Heuskin, S. (2017). Chemical composition and acaricidal activity of Thymus algeriensis essential oil against Varroa destructor. Natural product communications, 12(1), 1934578X1701200138.

Küçükyılmaz, K., Kıyma, Z., Akdağ, A., Çetinkaya, M., Atalay, H., Ateş, A., ... Bozkurt, M. (2017). Effect of lavender (Lavandula stoechas) essential oil on growth performance, carcass characteristics, meat quality and antioxidant status of broilers. South African Journal of Animal Science, 47(2), 178-186.

Li, L., Lin, Z. G., Wang, S., Su, X. L., Gong, H. R., Li, H. L., ... Zheng, H. Q. (2017). The effects of clove oil on the enzyme activity of Varroa destructor Anderson and Trueman (Arachnida: Acari: Varroidae). Saudi Journal of Biological Sciences, 24(5), 996-1000.

Lin, Z., Su, X., Wang, S., Ji, T., Hu, F. L., \& Zheng, H. Q. (2020). Fumigant toxicity of eleven Chinese herbal essential oils against an ectoparasitic mite (Varroa destructor) of the honey bee (Apis mellifera). Journal of Apicultural Research, 59(2), 204-210.

Losa, R. (2001). The use of essential oils in animal nutrition. Cahiers Options Mediterraneennes, 54, 39-44.

Manning, R., Speijers, J., Harvey, M., \& Black, J. (2010). Added vegetable and fish oils to low-fat pollen diets: effect on honey bee (Apis mellifera L.) consumption. Australian journal of entomology, 49(2), 182-189.

Mert, G., Yücel, B., \& Kösoğlu, M. (2007). Bal Arısı Hastalık ve Zararlıları İle Organik Mücadele Yöntemleri. Hasad Hayvancilik, 261,263, 62-64, 52-58.

Niculae, M., Spînu, M., Şandru, C. D., Brudaşcă, F., Cadar, D., Szakacs, B., \& Mateş, C. I. (2009). Antimicrobial potential of some Lamiaceae essential oils against animal multiresistant bacteria. Lucrări Științifice Medicină Veterinară Timișoara, 42, 170-175.

Novak, J., Zitterl-Eglseer, K., Deans, S.G., \& Franz, C.M. (2001). Essential oils of different cultivars of Cannabis sativa $\mathrm{L}$. and their antimicrobial activity. Flavour and fragrance journal, 16(4), 259-262.

Pătruıcă, S., Moț, D., \& Popovicı, D. (2017). The effect of using medicinal plant extracts upon the health of bee colonies. Retrieved from https://www.rombio.eu/docs/RBL10675.pdf

Palazzolo, E., Laudicina, V., \& Germana, M. (2013). Current and potential use of citrus essential oils. Current Organic Chemistry, 17(17), 3042-3049.

Pinheiro, I. M., Luz, J. H. S., Souza, L. F. N., Oliveira, A. C., Oliveira, E. E., Aguiar, R. W., ... Tschoeke, P. H. (2019). Effects of Lippia sidoides Cham. (Verbenaceae) essential oils on the honey bees, Apis mellifera (Apidae: Hymenoptera), foraging. Revista de Ciencias Agrícolas, 36(E), 31-41. 
Porrini, M.P., Garrido, P.M., Gende, L.B., Rossini, C., Hermida, L., Marcángeli, J.A., \& Eguaras, M.J. (2017). Oral administration of essential oils and main components: Study on honey bee survival and Nosema ceranae development. Journal of Apicultural Research, 56(5), 616-624.

Razavi, S. M., Asadpour, M., Jafari, A. \& Malekpour, S. H. (2015). The field efficacy of Lepidium latifolium and Zataria multiflora methanolic extracts against Varroa destructor. Parasitology research, 114(11), 4233-4238.

Rusenova, N., \& Parvanov, P. (2009). Antimicrobial activities of twelve essential oils against microorganisms of veterinary importance. Trakia Journal of sciences, 7(1), 37-43.

Sabahi, Q., Gashout, H., Kelly, P. G., \& Guzman-Novoa, E. (2017). Continuous release of oregano oil effectively and safely controls Varroa destructor infestations in honey bee colonies in a northern climate. Experimental and Applied Acarology, 72(3), 263-275.

Simitzis, P.E. (2017). enrichment of animal diets with essential oils-a great perspective on improving animal performance and quality characteristics of the derived products. Medicines, 4(2), 35.

Su, X., Hua, Q., Zhao, D., Fei, Z., \& Zheng, H. (2016). The effect of essential oils of Truestar Anisetree against mites in honeybee colonies. Journal of Environmental Entomology, 38(6), 1251-1255.

Tauber, J.P., Collins, W.R., Schwarz, R.S., Chen, Y., Grubbs, K., Huang, Q., ... Evans, J.D. (2019). Natural product medicines for honey bees: Perspective and Protocols. Insects, 10(10), 356.

Tutkun, E. (2016). Arı Akarı (Varroa destructor) Mücadelesinde Timol'ün Kullanılması. Arıcılık Araştırma Dergisi, 8(1), 15.

Tutun, H., Koç, N., \& Kart, A. (2018). Plant essential oils used against some bee diseases. Turkish Journal of Agriculture-Food Science and Technology, 6(1), 34-45.

Ünal, A., \& Kocabağli, N. (2014). Effect of different dosages of oregano oil on performance and some blood parameters in lambs. Ankara Üniversitesi Veteriner Fakültesi Dergisi, 61, 199-204.

Witherell, P. C., \& Bruce, W. A. (1990). Varoa mite detection in beehives: evaluation of sampling methods using tobacco smoke, fluvalinate smoke, amitraz smoke and ether-roll. American Bee Journal, 130(2), 127-129.

Zeng, Z., Zhang, S., Wang, H., \& Piao, X. (2015). Essential oil and aromatic plants as feed additives in non-ruminant nutrition: a review. Journal of Animal Science and Biotechnology, 6(1), 7. 
